\title{
The Improving of Productive Questioning Skills Through the 3N Approach Assisted by Learning Videos.
}

\author{
$1^{\text {st }}$ Astuti Wijayanti ${ }^{1}, 2^{\text {nd }}$ Asri Widowati ${ }^{2}, 3^{\text {rd }}$ Ayu Fitri Amalia ${ }^{3}, 4^{\text {th }}$ Sigit Sujatmika ${ }^{4}, 5^{\text {th }}$ Setuju $^{5}, 6^{\text {th }}$ Bayu \\ R Setiadi ${ }^{6}$ \\ \{astuti.wijayanti@ustjogja.ac.id ${ }^{1}$, asri_widowati@uny.ac.id², ayufitriamalia@ustjogja.ac.id ${ }^{3}$, \\ sujatmika@ustjogja.ac.id ${ }^{4}$, setuju@ustjogja.ac.id ${ }^{5}$, bayursetiadi@ustjogja.ac.id $\left.{ }^{6}\right\}$
}

\begin{abstract}
Questioning skills are fundamental to achieving these 4Cs so it is important to develop. Skills to ask questions are also important things mastered by teachers and prospective teachers so that they can ask qualified questions. The purpose of this study was to improve the productive questioning skills of prospective science teachers by using learning videos and $3 \mathrm{~N}$ methods (Niteni, Nirokke, Nambahi). The design of this study is Classroom Action Research, which has stages (1) planning, (2) implementation/action, (3) observation, and (4) reflection. The subjects of this study were 34 students of Natural Sciences FKIP UST. The instrument used is an observation sheet. The data obtained were analyzed using quantitative descriptive. The results showed that video collaboration and the $3 \mathrm{~N}$ methods (Niteni, Nirokke, Nambahi) could increase the skill to submit productive questions as indicated by an increase of 4 questions in the first cycle to 15 productive questions in the second cycle.
\end{abstract}

Keywords. Teaching Materials, Digital, Sigil

\section{Introduction}

Era 4.0 requires 21 st-century skills that challenge an individual to be more creative so that the knowledge learned can function to produce valuable products rather than just gathering information. It is important for teachers to develop student learning and innovation skills, which are often referred to as "4C" which includes Creativity, Critical Thinking, Communication, Collaboration. But there are fundamental skills to be able to learn and innovate, namely curiosity and ask questions.

Skill in asking questions is not only a means of gathering information. Instead, by asking questions, students can identify their own knowledge gaps and think critically about what they learn, assess information from individuals and other sources of information, think creatively and differently, and work constructively with others. Curiosity and question formulation skills support $4 \mathrm{Cs}$ while also utilizing skills that are not highlighted in the Framework for 21st Century Learning.

Science education aims to enable students to use scientific process skills to be able to define problems around them, to observe, analyze, hypothesize, experiment, conclude, generalize, and apply the information they have with the necessary skills[1]. Questions are one of the core skills of inquiry and the scientific foundation of teaching and learning that 
educators and students need to have. Question-based learning requires questions that lead to the inquiry where students learn to understand the content of the subject. According Tofade, questions are one of the most powerful teaching tools that can significantly improve the quality of teaching[2]. Therefore, Almeida [3] adds that an educator needs to place a focus on students' questions rather than on educator questions, and assessing students' questions rather than emphasizing their responses are important in supporting higher students' thinking levels. Essential questioning skills are mastered by the teacher so that they can ask quality questions[4]. Therefore, important teacher candidates are trained to skillfully ask productive questions.

The rapid development of science and technology and the continued spread of information have enabled people to expand channels to gain knowledge[5]. Likewise with learning that will achieve optimal results if it is facilitated by a variety of learning tools from the aspect of approaches, methods, media or evaluation systems, individually, in groups, or also classically[6]. The application of media with the Niteni, Nirokke and Nambahi (3N) approach will help students to understand the concept of learning material presented interactively and able to provide information and a better learning process. It will reduce oral descriptions from educators with educators to be more learning managers so that they can pay more attention to other aspects of learning. Learning media used will be able to arouse curiosity, stimulate students to be interactive in learning. Learners can more easily describe a problem, a concept, a process or procedure that is abstract and incomplete becomes clearer and more complete. The purpose of this study was to describe the application of learning video collaboration with the approach of $3 \mathrm{~N}$ to improve productive questioning skills of prospective science teachers.

\section{Method}

This research is a Class Action Research consisting of (1) planning, (2) implementation/action, (3) observation, and (4) reflection. This study was conducted from February 2018 to October 2018 at the Science Education Department of FKIP, Universitas Sarjanawiyata Tamansiswa in the course of Basic Science Teaching Ability (KDM). The subjects of this study were 34 students. In order to obtain information about the activities of lecturers and students in implementing collaborative learning media using the approach of $3 \mathrm{~N}$ observation sheets used.

\section{Results And Discussions}

This classroom action research was conducted in two cycles. Explanation of the cycle implementation as follows.

\subsection{Cycle}

In the first cycle, it was held for five meetings, namely the first meeting on February $27^{\text {th }} 2018$ with the material for further questioning skills. the second meeting was on March $6^{\text {th }} 2018$, with the simulation of advanced questioning skills. the third meeting on March $27^{\text {th }}$ and fourth meeting on April $3^{\text {rd }} 2018$, with the skills to provide variations and explanations. The fifth meeting on April $10^{\text {th }} 2018$ the evaluation and filling out of the questionnaire. 


\subsubsection{Planning}

The activities at the planning stage included: 1) Preparing the Learning Event Unit with the approach of $3 \mathrm{~N}$; 2) Providing media to be used in learning; 3) Preparing lecturer and student observation sheets with $3 \mathrm{~N}$ approach, and 4) Preparing evaluation tools to measure productive questioning skills at the end of each cycle.

\subsubsection{Do}

At this stage, the lecturer carries out learning with the approach of $3 \mathrm{~N}$ that have been arranged in the planning stage. Description of the implementation of $1^{\text {st }}$ Cycle actions as follows:

The lecturer conditions students to sit neatly and ask students to look at (Niteni) the learning/media videos displayed. However, the classroom was too bright so students sitting on the back were less clear in observing. Video sound was less loud. The lecturer has not explained yet clearly what students need to pay attention in the video shown. After the video ends, the lecturer invited students to component components and the example/model behaviour in the video. Question and answer were done by the lecturer to provoke what is understood by students after observing KDM learning videos. However, students were still reluctant to give opinions, ask questions and tend to appear shy to answer questions from lecturers. The lecturer tries to provide another picture so that students can answer and understand the KDM components contained in the video. Students who were active in discussions were still dominated by certain people.

Lecturers have divided students based on academic achievement, activity, and gender. The atmosphere became somewhat rowdy when conditioning students to sit with the group. The lecturer has not asked for one of the group leaders. The lecturer conveyed to each group to be able to share the role of teacher and student in the scenario that will be created.

In the next stage, students were asked to Nirokke what has been done before. The lecturer asked each group to make a science material scenario for Junior High School in accordance with the video that was observed. The material between groups was different from one another. Students discuss made simulations related to the material being studied in their chosen science material. Lecturers have not travelled to all groups and have not checked which components are still missing in all groups. It appears, the group had difficulty in creating scenarios or Nirokke because there were some forgotten components, especially in groups that did not have records.

The lecturers asked the group representatives to simulate the scenarios they made. Lecturers conditioned students and provide guidance that on this occasion they were tasked with observing simulations conducted by other groups. The lecturer has not yet asked or obliged the observer group clearly what they need to do when observing, especially not asking yet to make a question of what will be observed from other group simulations. Students seem relaxed, some are still busy discussing their unfinished scenario, but each group could already condition their respective groups.

At the stage of scenario modelling in the simulation, students added to the movements according to the expected role and material scenario created. No student group has volunteered to advance first so that the lecturer immediately appoints the group that was deemed ready to simulate the scenario. Previous lecturers have not asked for each group member to duplicate the finished scenario. Existing scenarios did not yet have copies. The division of characters in the simulation has not gone well so that the voice and expression of each role were not yet clear. Some students have not been seen making questions or finding things that will be improved related to the components of the material being simulated. 
Lecturers also have not given the time limit for the appearance of group simulations so that the learning time became less efficient.

At the discussion and evaluation stage, the lecturer has not provided a clear time limit. Some groups have not been able to analyze and provide component input that was not yet appropriate in simulations conducted by other groups. Some student groups have not been able to exemplify what was still wrong and correct it with concrete behaviour. Lecturers have not given other groups the opportunity to respond because of time constraints. In addition, questions from the observer group rarely appear. It has resulted in not all the main focuses have been well discussed. From the scenario, some groups already exist that raise productive questions and quality questions.

Replaying from other groups was based on the activities of other groups after Nirokke from the appearance of the previous group simulation with different science materials. Other groups seemed enthusiastic to display their scenario simulation. The lecturer invited the group to be able to simulate the scenario. Some students are ready to display their scenario. They feel more confident after seeing the previous appearance. However, at the time of play, some actors still did not focus on their respective roles and sometimes there were reactions from other observers that disturbed their concentration in carrying out their roles.

The next stage is the stage of discussion and evaluation. Lecturers provoked the simulated KDM component analysis by giving several questions so that the main focus in each skill component can be understood by students. However, at this stage, it appears that only certain people could actively discuss. Other students seemed to sit quietly and wait for answers and additions from the lecturers. Lecturers have not been optimal in asking further questions so they have not been able to lead students' answers to the components in question.

The phase of sharing and generalizing experience, students were invited to Niteni and Nambahi what was being discussed with the lecturer. Lecturers asked student representatives to retell what they experienced or meet and feel at school or attend lectures and analyze how a teacher should overcome problems in teaching so that their students will experience and feel learning that was interesting, challenging and fun someday. But at this stage, not all of the student groups could actively argue linking the situation played with other life/problems.

\subsubsection{Observation/Monitoring}

Based on the observations of researchers and collaborators, the results of observations of lecturer and student activities in the implementation of collaborative learning videos and $3 \mathrm{~N}$ approaches to the KDM courses are as follows:

The implementation of learning using the $3 \mathrm{~N}$ approach assisted video learning has been carried out in accordance with the planning. However, the lecturer still has shortcomings in several ways. Lecturers have not been able to focus students' attention on the videos displayed optimally; 2) Classrooms were too bright so students sitting on the back are less clear in observing; 3) Video sound was less loud; 4) Lecturers have not explained clearly what will be done by students; 5) The lecturer has not asked for one of the group leaders; 6) Lecturers have not traveled to all groups and have not checked which components are still missing in all groups; 8) The lecturer has not asked or obliged the observer group clearly what they need to do when observing, especially not asking to make a question of what will be observed from other group simulations; 9) The lecturer directly appointed the group that is deemed ready to simulate the results of the scenario; 10) Previous lecturers have not asked for multiplication of ready-made scenarios for each group; 11) Lecturers also have not given time limits on role playing / group simulation performances; 12) Lecturers have not provided a clear time limit; 13) Lecturers have not given other groups the opportunity to respond because of time 
constraints; 14) Not all of the main focuses have been well discussed; and 15) Lecturers have not been optimal in asking further questions so that they cannot lead students' answers to the components in question.

Student activities in learning were observed to be still lacking in several respects, namely: 1) Some students appeared to be taking notes and others were still observing the video; 2) Students were still reluctant to give opinions and tend to appear shy to answer lecturers' questions; 3) Active students were still dominated by certain people; 4) The atmosphere became somewhat noisy when conditioning students to sit with their group; 5) Some groups have difficulty in creating scenarios or nirokke because there were some components that are forgotten, especially in groups that do not have records; 6) Students seem relaxed, some were still busy discussing their unfinished scenario, 7) There were no student groups that have volunteered to advance first to display the scenario; 8) Students have not prepared scenario papers for a number of group members, so it took time to share the photo scenarios on the cellphones of each group member; 9) The voice and expression of each role were not yet clear; 10) Some students have not been seen making questions or finding things that will be improved related to the components of the material been simulated; 11) Some groups have not been able to analyze and provide input components that were not yet appropriate in simulations conducted by other groups; 12) Some student groups have not been able to exemplify which were still wrong and correct with concrete behaviour; 13) Questions rarely arise from the observer group; 14) Some actors still do not focus on their respective roles and sometimes there are reactions from other observers that disturb their concentration in carrying out roles; 15) Only certain people could actively discuss. Other students seemed to sit quietly and wait for answers and additions from lecturers; and 16) Not all student groups could actively argue about connecting the situation played by other life/problems.

\subsubsection{Reflection}

Some recommendations for actions that need to be taken as improvements in the implementation of $2^{\text {nd }}$ cycle are as follows:

The lecturer focused the students' attention on getting the video displayed by giving direction what students needed to do when the video played. After that, the dark classroom was made dark in order to make the clearer video display. The lecturer asked each video group to be aired by making a concept map to make it easier to understand each component of the skill. After that, the dark classroom was made dark in order to make the clearer video display. The lecturer asked each group to Niteni video aired by making a concept map to make it easier to understand each component of the skill. Then, one of the group representatives presented the concept map and asked for another group to Niteni and Nirokke what was explained by completing the group concept map. The use of notebook and Androids was maximized. Lecturers toured all groups, checked and directed. So that, the scenarios for each skill component were not overlooked in all groups, especially on how to ask questions in discussions and scenario-making tasks. The lecturer reminded us of things that need to be considered during the simulation/playing process, especially at the time limit, voice clarity and the meaning of each role. The lecturers asked or required the observer groups to Niteni by analyzing and making a few questions from what will be observed from other group simulations and adding if there were new things that they find from the appearance of other groups. The lecturer asked several groups to exemplify and argue from the role of other groups with concrete behaviour and connect the situation played with other life/problems. 


\subsection{Cycle}

In the second cycle, it carried out five times. The first meeting was on April 12 2018, with the skills to open and close learning. The second meeting was on April 24 2018, with the simulation material for the skills of opening and closing learning. The third meeting on May 6 , 2018, with the skills material for guiding small group. The fourth meeting on 3 April 2018 with a skill simulation of guiding for small groups. The fifth meeting on April 22 2018, for the evaluation and filling out of the questionnaire. The planning stage in the second cycle was carried out the same as planning in the second cycle, but with different material and design improvements in the core activities of KMD lectures. The action implementation in the second cycle can be carried out according to the suggested improvements in the reflection of the $1^{\text {st }}$ cycle.

Lecturers conditioned the room to be dark when students learn video, asked for a sitting position forward, used the speaker and asked students to be quiet so that the sound was clearer. The lecturers asked each group at the time of Niteni to also record or Nirokke what was in the KDM learning video on each teaching skill for prospective science teachers by using concept maps to make it easier to understand each component of the skill. The lecturer asked one of the group representatives to present a concept map made at the time of Niteni, another group Niteni and Nirokke explained by the group so that all the main focuses could be understood well by all. Then, the lecturer said that the task to display the scenario was a group other than those who had presented at previous meetings. All students were agreed and welcomed the decision enthusiastically.

The lecturer asks the students to Nirokke what they have been asked before by asking (Niteni) each group to make a scenario according to the observed video and concept map. Scenarios made by discussing different science materials for Junior High School. Students discussed in making simulations related to the studied material in their chosen science material. The lecturer asked each group to be able to provide a description of what used components in the scenario by giving a square mark on the made sample dialogue. Each group could work on several components in each skill to be in the included scenario. Lecturers provided clear explanations of tasks to students such as preparing scenarios using notebooks so that it was easier to share documents both via email and android. Students were allowed to access cellphones both to access learning resources and to share scenario documents with other members. The lecturers had travelled to all groups, checked and directed that the scenarios for each component of the skills were not missed in all groups. Each group seems to have been enthusiastic about composing scenarios because each group had a clear concept map. So that, it can help to facilitate remembering each major concept in each of the studied basic teaching skills. The lecturer also directed and provided examples of ways to make quality questions and asked productively both on the scenarios created and questions for other groups. This could be seen from the scenario of students who have written down the description of each skill component, the types of questions that appear in the learning and variated KDM scenarios and got better from the 1st cycle.

The lecturer requested or obliged the observer group to carefully Niteni what the other groups were simulated and asked to analyze according to the concept map notes and made some questions of what will be observed from other group simulations. Lecturers have given a clear time limit for each stage of the simulation method, especially on role-playing/group simulation performances. Students who appear to have added with the expression according to the expected role and the material scenario made. Students voluntarily displayed their scenario results in front of the class. It seems that the present group is more ready and systematic and time efficient. It was because each group member had a scenario and was well aware of its 
role. The other groups seemed to discuss comparing and analyze each component they had titeni in the previous stage. Some students could be active to add by responding to what was it titeni. Student groups had been able to actively provide opinions, questions and exemplify which ones were still wrong and correct with behaviouristic concrete.

Other group students did Nirokke from the appearance of previous group simulations with different science materials. The lecturer invited groups that had not yet been presented to be able to simulate the scenario. Students have displayed their scenario voluntarily. The role of appearance in the simulation was more ensoul and natural. They have been able to focus the scenarios that are made with the main components in each skill being studied.

Lecturers improved the way to submit further questions in the discussion and evaluation stages so that they could lead students' answers to the components in question. Lecturers moved their turn to ask questions and argue that not only certain people can discuss actively. The lecturer also asked several groups to exemplify and argue from the role of other groups with concrete behaviour. The lecturer directed the relationship between the situation played by life/other problems. Some groups had actively participated in expressing their experiences, and some groups could respond and provide solutions to the arise problems at this stage.

\subsubsection{Observations / Monitoring Actions}

Lecturers had carried out the steps of the simulation method of $3 \mathrm{~N}$ based had been carried out in accordance with the planning and improvements in accordance with the recommendations suggested in the $1^{\text {st }}$ cycle. In the $2^{\text {nd }}$ cycle, the lecturer felt that the IPA' KDM class was more alive and the discussion in each group had been optimal. The tasks given by the lecturer can be completed on time. Students had implemented the simulation method steps with $3 \mathrm{~N}$ based according to the direction of the lecturer. In this $2^{\text {nd }}$ cycle, students seemed enthusiastic. Each student seemed to be active in giving questions, opinions. They could take roles as well so that the scenario could be completed on time and well presented by each group.

\subsubsection{Reflection}

Based on the problems discussed with collaborators, the lecturer captured and improved and implemented the solutions offered / mutually agreed upon in the implementation of the $1^{\text {st }}$ cycle so as not to experience new problems. Researchers and collaborators decided that in $2^{\text {nd }}$ cycle the indicators of learning success had been achieved as expected. Productive skills questioning for science teacher prospectives in the $1^{\text {st }}$ and $2^{\text {nd }}$ cycle can be shown in Figure 1. Concrete visual use could attract interest in finding material concepts because they could describe subject matter and provide concrete experiences to make the learning process easy[7]. Learning by using the dual senses of sight and hearing could provide benefits for students to better understand the material described by the teacher[8]. When students could control their learning, they asked questions that were more profound and open. These questions could lead to increased knowledge, understanding the process of science, and reasoning skills[9]. 


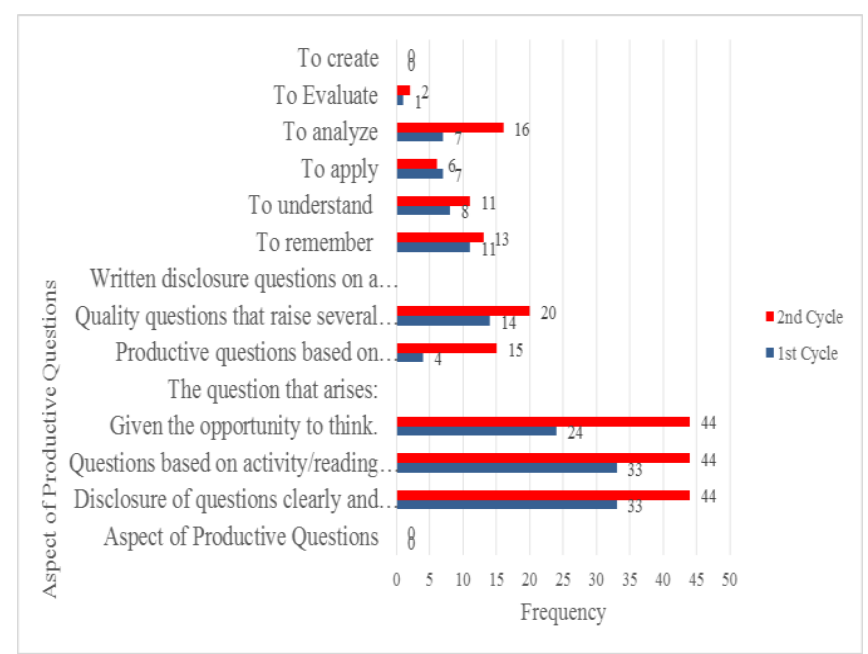

Fig. 1. Comparison of productive questioning skills for natural science teacher prospective in the 1st cycle and 2nd cycle

\section{Conclusion}

Based on the results of data analysis and literacy studies, it can be concluded that collaborative learning videos and $3 \mathrm{~N}$ (Niteni, Nirokke and Nambahi) approaches can improve productive questioning skills for prospective science teachers. Productive questions that arise were increasing from 4 questions in the 1 st cycle to 15 productive questions in the 2 nd cycle. High-level questions increase in the 2nd cycle. Educators should be able to be facilitators in $3 \mathrm{~N}$-based learning so that students can be active and creative in finding material concepts by asking productive questions in each lesson.

\section{Acknowledgment}

We are grateful to teamwork. This research is based upon work supported by DIPA Kopertis V.

\section{References}


[1] H. Aktamis and O. Ergin, "The Effect of Scientific Process Skills Education on Students' Scientific Creativity, Science Attitudes and Academic Achievements," AsiaPacific Forum Sci. Learn. Teach., vol. 9, no. 1, p. 21, 2008.

[2] P. B. Adnyana and D. M. Citrawathi, "The Effectiveness of Question-Based Inquiry Module in Learning Biological Knowledge and Science Process Skills," Int. J. Environ. Sci. Educ., vol. 12, no. 8, pp. 1871-1878, 2017.

[3] P. A. Almeida, "Can i ask a question? The importance of classroom questioning," Procedia - Soc. Behav. Sci., vol. 31, no. 2011, pp. 634-638, 2012.

[4] X. Ma, “The Skills of Teacher's Questioning in English Classes,” Int. Educ. Stud., vol. 1, no. 4, pp. 92-100, 2009.

[5] Y. Jiang, "The Effective Application of Fragmented Learning Guided by Constructivism," vol. 3, no. 1, pp. 10-13, 2018.

[6] M. S. B. \& M. S. B. Wiana Winwin, "The Effectiveness of Using Interactive Multimedia Based on Motion Graphic in Concept Mastering Enhancement and Fashion Designing Skill in Digital Format," pp. 4-20.

[7] S. H. Anwariningsih, "Development of Interactive Media for ICT Learning at Elementary School Based on Student Self Learning," vol. 7, no. 154, pp. 121-128, 2013.

[8] D. Yunita and A. Wijayanti, "Pengaruh Media Video Pembelajaran Terhadap Hasil Belajar IPA Ditinjau dari Keaktifan Siswa," Sosiohumaniora J. Ilm. Ilmu Sos. dan Hum., vol. 3, no. 2, pp. 153-160, 2017.

[9] N. Hanegan, K. Friden, and C. R. Nelson, "Authentic and Simulated Professional Development: Teachers Reflect What is Modeled," Sch. Sci. Math., vol. 109, no. 2, pp. 7994, 2010. 